\title{
Chaos and complexity reign in the New Mexico mountains
}

Santa Fe, New Mexico

BARELY three years old, the Santa Fe Institute (SFI) can hardly be accused of having modest goals. "We are trying to define the scientific and educational agenda for the twenty-first century", says David Pines, University of Illinois physicist and co-chair of the SFI's science panel. The immediate challenge for the institute is to find funds among traditional sources for some non-traditional ideas.

From the outside, SFI is unassuming. It is located in a converted convent, a brief walk from the state capital, down a road fanous for its art galleries and craft stores. But inside there have been inter-

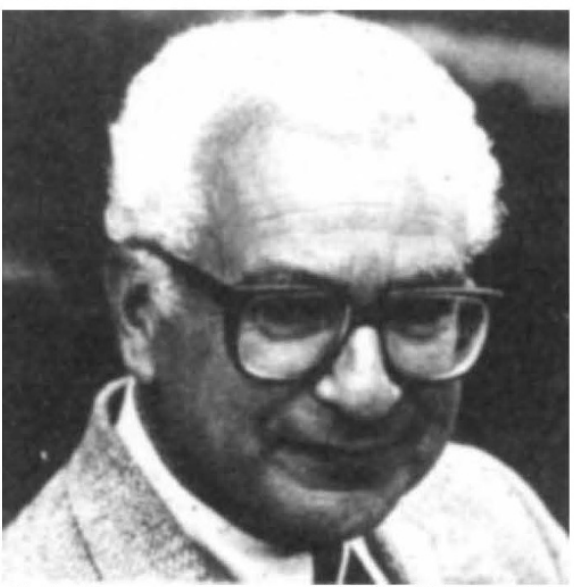

Gell-Mann - who says SFI should provide a nurturing environment for those looking to cross traditional boundaries.

esting goings on. Throughout the past summer, SFI has hosted a series of meetings and workshops to begin the process central to its goal of helping to catalyse new, interdisciplinary approaches to understanding complex systems.

A recent example was a meeting dubbed "Evolutionary paths of the global economy", co-chaired by physicist Philip Anderson of Princeton University and economist Kenneth Arrow of Stanford University - both Nobel prize winners. Sponsored by Citicorp and the Russel Sage Foundation, the meeting brought together economists and physical and biological scientists who have used nonlinear dynamic models to study adaptive paths.

Other intriguing topics discussed this summer include the matrix of biological knowledge - an attempt to bring the tools of computer science and artificial intelligence to bear on the increasing volume of biological and clinical data theoretical immunology, and a meeting this week on computational approaches to evolutionary biology.

SFI president George Cowan, who is also a senior fellow at nearby Los Alamos National Laboratory, says there are many visions of how the institute might evolve. Physicist Murray Gell-Mann of the California Institute of Technology is one of SFI's founders, serving now as cochairman of the science board and a member of the board of trustees. He sees SFI as providing an alternative to univer sities where it is difficult to foster interdisciplinary interactions. Gell-Mann says interdisciplinary centres are often relegated to the basement of a university-owned but unused Victorian mansion, with staffs forced to survive on short-term grants, shunned by the academic departments to which the centres nominally belong.

SFI currently maintains a small permanent staff. If money is found to support expansion, the core will stay small, but there will be a coterie of visiting faculty and graduate and postgraduate students.
SFI has been surviving on foundation grants and private contributions. But word is expected shortly on two multimillion dollar grant applications, one to the National Science Foundation and one to the Department of Energy. There is apprehension among SFI officials that the grants may be difficult to get, since the institute does not fall into a convenient category.

The proximity of the Energy Department's Los Alamos National Laboratory has a significant influence on SFI. Many of SFI's board members are affiliated with the national laboratory, and SFI co-hosted with the Los Alamos Center for Nonlinear Studies a workshop on artificial life.

There is no unanimity among board members about the specific paths SFI should take. But those actively involved with the institute radiate an excitement about its potential, and they believe that through the interaction of talented people there may well arise new visions of how the world is put together. Joseph Palca

\section{Eastern bloc exchanges may benefit from new rules}

\section{London}

THE inflexible regulations and complicated red tape that have made life difficult for Soviet scientists working abroad should be eased, the authorities claim, with the recent changes in Soviet rules for travel. Existing Soviet procedures on foreign assignments for scientists and technologists have come under strong criticism of late - both from a senior Soviet diplomat and the scientists themselves. Interviewed by Izvestiya, Strizhkov, the Deputy Economic Counsellor at the Soviet Embassy in Sofia, said that although 376 Soviet specialists are now established at Kozlodui, where they are officially assisting the Bulgarians in the construction of a nuclear power station, many of them are not required at the present time.

The Soviet practice is to send such persons abroad on a two-to-three years' posting; however, many of them are actually required on the site only for a series of relatively short periods, and, if the paper-work permitted, could easily return to the Soviet Union in between. Unfortunately, no one will send them home, since there is no guarantee that they will be able to return when required. And, if a particular specialist has completed his term at the site, he has to go back to the Soviet Union, even if the task for which he has come has not been completed.

Plans for the supply of Soviet specialists to such projects are laid down in advance and until now there has been no provision made for change of schedule or emergency. Izvestiya quoted a case where problems arose with equipment supplied to Kozlodui by a Hungarian plant, a West German firm and the Soviet Tulaelektroprivod trust. Hungarian and West German trouble-shooters were on site within a week; the Soviet team arrived six months later. The latest changes, it is hoped, will make such "emergency visits" easier.

As well as keeping specialists idling abroad, long-term postings mean the need to support a considerable infrastructure: the Soviet colony at Kozlodui usually contains 800 to 1,000 persons, with inevitable problems of housing, transport, medical services, children's schooling and so on.

There is considerable pressure from the Kozlodui Soviet colony, Izvestiya said, for such "fraternal assistance" to be organized on a task-basis rather than a timebasis. Such a view-point is likely to receive considerable support from Soviet industrial managers. Until now, managers have been reluctant to have their specialists and scientific staff coopted, since although the host country paid for all technical services provided by the Soviet Union, none of this money filtered back to the enterprise which provided the specialists. Under the new Law on the State Enterprise, adopted on 1 July, all foreign "economic activity" including the "export" of consultancy and technical services, will be considered as part of its overall performance. Enterprise managers will therefore wish all such foreign "activity" to be planned on a basis of cost-effectiveness, and, Izvestiya argues, will favour any scheme which gets the specialist back to his or her regular job as soon as possible. 